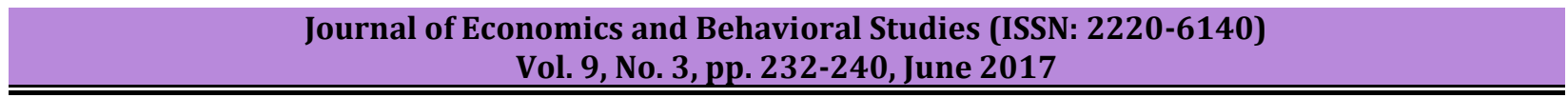

\title{
The Relationship between Learning Orientation and the Performance of Small and Medium Enterprises in South Africa
}

\author{
Evelyn Motsepe, Olawale Fatoki \\ Department of Business Management, University of Limpopo, South Africa \\ motsepeevelyn@yahoo.co.za, olawale.fatoki@ul.ac.za
}

\begin{abstract}
Small and medium enterprises (SMEs) are an important vehicle in income re-distribution, poverty alleviation, employment creation and contribute to the gross domestic product of South Africa. However, SMEs in South Africa suffer from a weak level of performance and a high failure rate. The main objective of this study was to investigate the impact of learning orientation on the performance of SMEs. A quantitative approach was used, while a self-administered questionnaire was also employed during data collection process. A three- section questionnaire covering demographic information, learning orientation variables and performance variables was prepared and distributed randomly to a selected sample of 390 SME owners in Msukaligwa Local Municipality in Mpumalanga Province of South Africa. A total of 181 questionnaires were returned. Descriptive statistics, factor analysis, correlation and regression analysis were used for data analysis. The Cronbach's alpha was used to measure reliability. The results of the study revealed a significant positive relationship between learning orientation and the performance of SMEs. Recommendations to improve the learning orientation of SMEs are suggested.
\end{abstract}

Keywords: Learning orientation, performance; SMEs, South Africa

\section{Introduction}

Fatoki and Garwe (2010) point out that small and medium enterprises (SMEs) are central pillars of economic growth of most countries. Thus, countries all over the world concentrate on broadening the SME sector in order to accelerate economic growth. SMEs are of great socio-economic significance (Small Enterprise Development Agency, 2012). The SME sector is one of the solutions to the high levels of poverty and income inequality in South Africa (Abor \& Quartey, 2010). SMEs account for approximately 91\% of formal business entities in South Africa. In addition, SMEs contribute about $50 \%$ of the gross domestic product and $60 \%$ of employment in South Africa (Department of Trade and Industry, 2012). Unsurprisingly, SMEs have been focused on by the government as a priority for job creation to reduce the high rate of unemployment estimated to be $27.1 \%$ (Statistics South Africa, 2016). However, despite their contribution to employment creation and economic growth, SMEs suffer from a high failure rate with a negative impact on the South African economy. Approximately 75\% of new SMEs in South Africa fail within the first five years of creation (Willesse, 2010). According to Van Scheers (2012:5051), some of the major challenges experienced by SMEs in South Africa are related to learning and marketing. This includes high competition, lack of managerial skills and unwillingness to attend training and seminars. Additionally, SMEs in South Africa suffer from access to finance. This results in high rate of SME failure in South Africa (Herrington \& Kew, 2013).

The adoption of learning orientation can positively impact on the performance of SMEs (Rebelo \& Gomes, 2011). A learning orientation focuses on understanding the relationship a firm places on its environment relative to both the customer and the competitor (Mahmood \& Hanafi, 2013). Bakar et al. (2016) argue that understanding the environment a firm operates in through the learning orientation enables the business to exploit opportunities as they arise while at the same time working on minimising the threats beforehand. Beneke et al. (2016) remark that adopting learning orientation allows a firm to meet and surpass customer expectations. On that note, Haryanto, Haryono and Sawitri (2017) assert that an organisation which embrace learning orientation has a high probability of becoming a market leader.Given the fact that customers in the $211^{\text {st }}$ century are becoming so knowledgeable about the products they buy and make comparisons before they buy, it is important for SMEs to utilise learning orientation to constantly meet their customer needs and remain profitable. However, the literature is inconclusive about the relationship between learning orientation and the performance of SMEs. In addition, the vast majority of studies on learning orientation have been done in developed countries (Dubihlela, 2013). The inconclusiveness of previous empirical studies and the lack of studies in South Africa on the effect of learning orientation on the performance of SMEs necessitated this study. Therefore, empirical findings of this study will contribute to the body of knowledge on learning 
orientation in South Africa as well as assisting managers to minimise the rate of business discontinuance in this country.

Objectives of the Study-The objectives of the study are:

- To understand the learning orientation of SMEs in South Africa.

- To investigate the relationship between learning orientation and the performance of SMEs in South Africa.

\section{Literature Review}

Definition of Learning orientation: Learning is a process of continuous information dissemination, processing and utilisation, often used by organisations as a strategy to gain competitive advantage (Chang \& Lee, 2007; Ayse, 2010; Jyathibabu, Pradhan \& Faroog, 2010). Learning is viewed as the strategy used to govern and integrate the internal and external environments (Liu, 2012). According to Nasution, Mavondo, Matanda and Ndubisi (2011), learning is a technique used by organisations to combine or merge internal information. Kreiser (2011) points out that learning is the result of acquiring knowledge combined with an actual act which SMEs put into practice.Learning orientation is a tool used by organisations to develop and improve their capabilities in order to be competitive in an ever-changing market environment (Rhee, Park \& Lee, 2010). Learning orientation opens new paths and enhances creative ways of doing business (Baker \& Sinkula, 2007). Learning orientation is an organisational behaviour that intends to influence knowledge sharing, interpretation and renewal between employees and shareholders in inter-firm relationships (Lai, Pai, Yang \& Lin, 2009). Akhtar et al. (2011) point out that a learning organisation is represented by three dimensions. These are (1) collectively committing to learning, (2) vision and (3) broad-mindedness. Learning-oriented organisations are often the best competitors in the market. Learning organisations easily and quickly keep up with rapid environmental changes (Konidari \& Yvan, 2006; Saru, 2007:36).

Theory of learning orientation: Suliyanto and Rahab (2012) describe learning orientation as the value of learning on the interior of an organisation. A greater level of learning in an organisation is an indication of devotion to learning as a practice (Dill \& Van Vught, 2010; Nybakk, 2012; Hussein, Mohamad, Noordin \& Ishak, 2014). A learning organisation focuses on understanding customers as a process used to effectively satisfy their needs through new products and services (Altbach, Reisberg \& Rumbley, 2009; Mahmood and Hanafi, 2013). The resource based view acknowledges competitive edge as the outcome of unique inputs that have been identified and specified by an organisation (Barney, 1991). An example of such resources is relationship building capacity. Learning oriented organisations have an advantage of being in a position to effectively and efficiently utilise their learning capabilities (Espedal, 2008). Lu, Zhou, Bruton and LI (2010) suggest that learning orientation permits a firm to comprehend the desires of consumers. As such a firm needs to learn customers' needs to formulate superior values and to secure a competitive edge in the marketplace (Lages, Silva, Style \& Pereira, 2009). Previous studies find that organisational learning is a significant factor in obtaining a competitive advantage (Abbasi, Akbari \& Tajeddini, 2015). Learning orientation has been observed as an essential variable directly linked to innovation (Rhee et al., 2010; Huang \& Wang, 2011). Learning orientation has a direct and positive influence on customer value (Nasution \& Mavondo, 2008).

The effect of learning orientation on the performance of SMEs: Lu, Zhou, Bruton and Li (2010) suggest that learning orientation permits a firm to comprehend the desires of consumers. As such a firm needs to learn customers' needs to formulate superior values and to secure a competitive edge in the marketplace (Lages, Silva, Style \& Pereira, 2009). Organisational learning is a significant factor in obtaining a competitive advantage (Abbasi, Akbari \& Tajeddini, 2015). Learning orientation has been observed as an essential variable directly linked to innovation (Rhee et al. 2010; Huang \& Wang, 2011). Learning orientation has a direct and positive influence on customer value (Nasution \& Mavondo, 2008). Studies by Bierly and Daly (2007), Hult, Ketchen and Slater (2007), Akhavan and Jafari (2008), Austin and Harkins (2008) and Nybakk (2012) found a significant positive relationship between learning orientation and the performance of SMEs. This can be attributed to the fact that learning orientation relates to vast organisational actions aimed at generating and providing information and awareness to build-up a competitive edge. Learning orientation is an organisation's ability to obtain, share, exploit and preserve relevant information (Jyathibabu et al., 2010). 
However, studies by Salavou (2005) and Eris, Ozmen and Neczan (2012) did not find a significant positive relationship between learning orientation and the performance of SMEs. This suggests that literature is inconclusive about the direction and strength of the relationship between learning orientation and the performance of SMEs. Despite the inconclusiveness of previous research, the argument of this study is that learning orientation positively impacts on the innovativeness of SMEs. Thus learning orientation can lead to competitive advantage, which can positively impact on the performance of SMEs. Thus, it is hypothesised that there is a significant positive relationship between learning orientation and the performance of SMEs.

\section{Methodology}

The study followed a quantitative research design with descriptive and causal research approaches. The study area was theMsukaligwa Municipality in the Mpumalanga province of South Africa.The survey method was used for data collection. Self-administered questionnaire method was used to collect data from the respondents. Convenience and snowball sampling methods were used to identify the respondents. The two sampling methods were used due to the inability to get a sampling frame of SMEs in the study area.The scale used to measure learning orientation was adapted from previous literature (Bierly \& Daly, 2007; Hult et al., 2007). The five-point Likert scale ranging from " 1 strongly disagree", " 2 disagree", " 3 neutral", " 4 agree" and "5 strongly agree" was used to measure learning orientation. The scale to measure performance was adapted from Idah and Mahmood (2011:1), with a Cronbach's alpha coefficient of 0.76 . The study used a four-point scale to measure performance. The five-point Likert scale ranging from " 1 significant decline", " 2 decline", "3 remained the same", " 4 increase" and " 5 significant increase" was used to measure performance. All the scales used by this study have acceptable psychometric properties in terms of their reliability and validity. The questionnaire was pre-tested with twenty owners of SMEs.This made it possible to identify and eliminate problems which might be faced later in the study as well as improving the face and content validity of the questionnaire following recommendations by (Cooper \& Schindler, 2008). The questionnaire was divided into three sections: A three- section A, covering demographic information, section B covering learning orientation variables and section C covering performance variables.Descriptive statistics, factor analysis, correlation and regression were used for data analysis. The Cronbach's alpha was used as a measure of reliability. A score of 0.7 is the acceptable reliability coefficient (Hair, Anderson, Tatham \& Black, 2006)

\section{Results and Discussion}

Response rate and demographic characteristics: Three hundred and ninety (390) questionnaires were sent out to the respondents and one hundred and eighty one (181) questionnaires were returned. The response rate was 46.4\%. 106 males and 75 females participated in the survey. The results indicate that females involved in business are still less than males in South Africa. Similarly, Tsele (2015) note that females are still underrepresented in business as their male counterparts continue to dominate. However, some studies attribute this to the fact that females are risk averse hence the low rate of starting and owning a business.The majority of the SME owners that participated in the survey were in the 30-39 age group with Matric qualification. This indicates that most businesses are run by the youthful generation in South Africa. The authors of this paper hence believes that this will make it easy to introduce the learning orientation to SMEs in South Africa since the youth have less resistance to change compared to old people.In addition, the majority of SMEs that took part in the survey were in the service and retail sectors, with between one and four employees and in operation for a period of six to ten years.

Descriptive statistics on learning orientation: Table 1 illustrates the results of descriptive analysis on learning orientation, of which two of the three items with the highest mean are: 'In this company learning is a necessity essential to secure the survival and longevity of the company' (mean 4.25) and 'Employees are dedicated to company goals in all sections (mean 4.25) are both equally important. This is followed by the item 'management team understood that a company's capability to learn serves as a competitive benefit' (mean=3.77). The three items with the lowest mean are: 'Employees see themselves co-partnering with management towards moving the company to the right direction' (mean=2.58); 'The company has a special technique of sharing previous experiences on company's actions in every section' (mean=2.71). The scale mean in table 1 is above 3, which shows a high level of learning orientation on SMEs. The results are 
consistent with the findings of previous empirical studies on learning orientation and performance (Akhavan and Jafari, 2008; Austin and Harkins, 2008; Nybakk, 2012; Mahmood and Hanafii, 2013).

Table 1: Descriptive analysis of learning orientation

\begin{tabular}{|c|c|c|}
\hline & Mean & Standard deviation \\
\hline $\begin{array}{l}\text { Management essentially concurs that our company's capability to } \\
\text { learn strengthen our competitive advantage }\end{array}$ & 3.77 & 1.044 \\
\hline $\begin{array}{l}\text { The understanding surrounding this argument is that it is a huge } \\
\text { investment for employees to learn and not expenditure }\end{array}$ & 3.75 & 1.044 \\
\hline $\begin{array}{l}\text { In this company learning is a necessity essential to secure the survival } \\
\text { and longevity of the company }\end{array}$ & 4.25 & 0.788 \\
\hline $\begin{array}{l}\text { We all understand and mutually agree with the company's aims and } \\
\text { visions in all sections and sub-sections }\end{array}$ & 3.75 & 1.085 \\
\hline Employees are dedicated to company goals in all sections & 4.25 & 0.793 \\
\hline $\begin{array}{l}\text { Employees see themselves co-partnering with management towards } \\
\text { moving the company to the right direction }\end{array}$ & 2.58 & 1.140 \\
\hline $\begin{array}{l}\text { The company staff found that their perceptions about the market place } \\
\text { is regularly questionable }\end{array}$ & 3.62 & 1.122 \\
\hline $\begin{array}{l}\text { The company consistently assesses the quality of decisions and actions } \\
\text { implemented afterwards }\end{array}$ & 3.69 & 1.113 \\
\hline $\begin{array}{l}\text { The company has a respectable communication platform which } \\
\text { revives previous lessons experienced }\end{array}$ & 3.52 & 1.077 \\
\hline $\begin{array}{l}\text { The company has a special technique of sharing previous experiences } \\
\text { on company's actions in every section }\end{array}$ & 2.71 & 1.218 \\
\hline $\begin{array}{l}\text { The company positioned a slight determination in sharing lessons and } \\
\text { experiences }\end{array}$ & 3.56 & 1.180 \\
\hline Scale mean & 3.59 & \\
\hline Standard deviation & 1.003 & \\
\hline Crombach's alpha & 0.842 & \\
\hline
\end{tabular}

Table 2: factor analysis of learning orientation

\begin{tabular}{ll}
\hline Item & Factor loading \\
\hline $\begin{array}{l}\text { In this company learning is a necessity essential to secure the survival and } \\
\text { longevity of the company }\end{array}$ & 0.937 \\
$\begin{array}{l}\text { Management essentially concurs that our company's capability to learn strengthen } \\
\text { our competitive advantage }\end{array}$ & 0.901 \\
$\begin{array}{l}\text { We all understand and mutually agree with the company's aims and visions in all } \\
\text { sections and sub-sections }\end{array}$ & 0.834 \\
$\begin{array}{l}\text { The understanding surrounding this argument is that it is a huge investment for } \\
\text { employees to learn and not expenditure }\end{array}$ & 0.803 \\
$\begin{array}{l}\text { The company consistently asses the quality of decision and actions implemented } \\
\text { afterward }\end{array}$ & 0.746 \\
$\begin{array}{l}\text { Employees are dedicated to company goals in all sections } \\
\text { The company consistently assesses the quality of decisions and actions }\end{array}$ & 0.636 \\
$\begin{array}{l}\text { implemented afterwards } \\
\text { company staff found that their perceptions about the market place is regularly }\end{array}$ & 0.588 \\
questionable & \\
$\begin{array}{l}\text { The company has a respectable communication platform which revives previous } \\
\text { lessons experienced }\end{array}$ & 0.527 \\
Percentage of variance explained: $66.561:$ KMO=0.917; BTS p<0.001 & \\
Items with loading below 0.300 removed &
\end{tabular}

Factor analysis of learning orientation: The principal component analysis with Varimax rotation was used for factor analysis. Table 2 displays a one-factor clarification of learning orientation with 66.561 of the total variance. Two out of the eleven items have been eliminated as a result of low loading), the items which are 
lower than .300 include: 'inthis company learning is a necessity essential to secure the survival and longevity of the company $=0.24$ '; as well as 'the company has a respectable communication platform which revives previous lessons experienced $=.28$ '. The validation of the variables used was done through factor analysis. The Kaiser-Meyer-Olkinmeasure of sampling adequacy (KMO) and Bartlett's Test of Sphericity were used to determine the suitability of the data. The acceptable high level of learning orientation is consistent with studies such as Kotabe, Dunlap-Hinkler, Parente \& Mishra (2007), Gnyawall, Singal \& Mu (2009) and Kafouros, Buckley \& Clegg (2012). The KMO must be at least 0.6. Learning orientation has a meaning and admissible Kaizer-Meyer-Olkin (KMO) of .817 . Bartlett's test of sphericity (BTS) $=2.161 \mathrm{E} 3, \mathrm{p}=0.000$, df= 78 .

Table 3: Descriptive analysis of performances

\begin{tabular}{lll}
\hline Performance variables & Mean & Std deviation \\
\hline Sales turnover & 3.75 & 1.017 \\
Profit & 2.16 & .950 \\
Employment & 1.91 & 1.034 \\
Sales growth compared to competitors & 3.67 & 1.131 \\
Valid N (listwise) & 4 & \\
Scale mean & 2.87 & \\
Std deviation & 1.106 & \\
Cronbach's Alpha & .708 & \\
\hline
\end{tabular}

Performance: Table 3 shows that descriptive analysis on performance confirmed that items with the highest mean is 'sales turnover' with (mean= 3.75), as well as 'sales growth compared to competitors' being second most important item (mean= 3.67). The item with the lowest mean is 'employment' with a (mean 1.91). This means that SMEs are still lagging behind in terms of employment growth. Studies such asWorld Bank (2015), assert that it is well known that smaller and younger firms are subject to more job destruction. On that note other studies such as (Masocha and Dzomonda 2016), indicates that SMEs employ mostly below 5 workerswhich is too low considering the high unemployment in South.The scale mean for performance is 2.87.The scale mean is low indicating that SMEs display an overall weak performance. This is consistent with similar studies such as (Machirori \& Fatoki, 2013).

Table 4: correlation between learning orientation and performance

\begin{tabular}{cll}
\hline & Learning orientation & Performance \\
\hline Learning orientation: Pearson correlation & 1 & .722 \\
Sig.(tailed) & & .000 \\
$\mathrm{~N}$ & 181 & 181 \\
& & \\
\hline
\end{tabular}

Table 5: Regression analysis between learning orientation and performance

\begin{tabular}{|c|c|c|c|c|c|}
\hline \multirow{2}{*}{ Model } & \multicolumn{2}{|c|}{ Unstandardized coefficient } & \multirow[t]{2}{*}{$\begin{array}{l}\text { Standardized } \\
\text { coefficient }\end{array}$} & \multirow[b]{2}{*}{$\mathbf{T}$} & \multirow[b]{2}{*}{ Sig } \\
\hline & $\mathbf{B}$ & $\begin{array}{l}\text { Std. Error of the } \\
\text { estimate }\end{array}$ & & & \\
\hline 1 (constant) & 3.161 & .234 & & 9.245 & .000 \\
\hline $\begin{array}{l}\text { Learning } \\
\text { orientation }\end{array}$ & .063 & .0 .10 & .722 & 6.270 & .000 \\
\hline
\end{tabular}

Dependent variable: Performance

The relationship between learning orientation and performance: Tables 4 and 5 present the results of the correlation and regression. The correlation between learning orientation and performance, which is $(\mathrm{r}=.722, \mathrm{p}=0.000)$. In this study the Pearson's $\mathrm{r}$ is .722, which is positive as it is closer to 1 . This means an increase in learning orientation value will result in an increase in the value of performance; similarly a decrease in learning orientation value will lead to a decrease in the value of SMEs performance. A strong 
correlation between learning orientation and performance has been affirmed with a sig value of less than 05 . The regression coefficient between learning orientation and performance is predicted by Beta $=.722, \mathrm{P}<.000$ with a significant $\mathrm{T}$ value 9.245, $\mathrm{P}<.000$ and $\mathrm{F}$ value of 2.601 and $\mathrm{P}<000$. The Beta $=.722$ which is closer to 1 supported by significant $P$ value of .000 concludes that the performance of SMEs can be predicted, based on efforts invested in learning orientation. Hence, the correlation results in table 4 and the regression analysis in table 5 indicate that there is a significant positive relationship between learning orientation and the performance of SMEs. The findings are consistent with previous (Bierly \& Daly, 2007; Hult, Ketchen and Slater, 2007; Akhavan and Jafari, 2008; Nybakk, 2012).

\section{Conclusion}

SMEs contribute positively to employment creation, poverty reduction and economic growth of South Africa. However, the failure rate of SMEs is very high in South Africa. The adoption of learning orientation can positively impact on the performance of SMEs. A learning orientation focuses on understanding the relationship a firm places on its environment relative to both the customer and the competitor. It was discovered that learning orientation allows a firm to be a market leader. Learning orientation also allows SMEs to be innovative which gives them a competitive advantage over their competitors. More importantly, it was found that learning orientation enable SMEs to build long lasting relationships with their customers. This critically improves their performance given the fact that customers in the $21^{\text {st }}$ century are knowledgeable about what to buy and where to get it cheap. Findings from the factor analysis for learning showed that majority of the factors were retained, therefore indicating construct validity of the scales. Considering the performance of SMEs, it was discovered that overally SMEs display a weak performance. The findings of existing studies were inconclusive about the direction of the relationship between learning orientation and the performance of SMEs. The current study investigated the relationship between learning orientation and the performance of SMEs. Considering the results from both correlation and regression analysis, the results revealed a significant positive relationship between learning orientation and the performance of SMEs. It was deduced that an increase in learning orientation value will result in an increase in the value of performance and at the same time a decrease in learning orientation value will lead to a decrease in the value of SMEs performance.

Recommendations: It was discovered that learning orientation positively influences the performance of SMEs. Hence, recommendations are made to the government and SME owner/managers to fully support the adoption and implementation thereof. The government has a bigger role to play in SMEs' development. Hence, as part of the package designed for SMEs, the government should organise workshops at all levels of its structures, that is from district level, provincial and national level where SMEs are taught on how to embrace learning orientation. Government Agencies such as the Small Business Development Agency (SEDA) and the National Youth Development Agency (NYDA) should organise formal trainings to promote and encourage SMEs to be more learning oriented. Learning is a continuous process which needs SMEs to continuously search for information in the business environment. Factors which affect the learning orientation of SMEs need to be improved. Hence, owners/managers in SMEs should thrive to create a culture that supports learning orientation. Furthermore, the management needs to adopt organizational structures which favor learning orientation. To fully yield the fruits of learning orientation, the adoption and implementation thereof should follow a holistic approach. This means that it should be supported from top management up to the shop floor workers. SMEs are also recommended to create a task team which specializes on checking customer complaints and feedback as well as benchmarking from competitor activities. Customer information must not only be acquired, but also disseminated and applied within the company, calling for attention to the importance of internal communication. As such, effective communication should be promoted in SME structures by making the communication to be two way. It is also crucial for the owners of SMEs to attend training and seminars on organizational learning. 


\section{References}

Abbasi, E., Akbari, M. \& Tajeddini, K. (2015). Organizational learning capabilities: evidence from the Iranian agricultural higher educational system. Iranian Journal of Management Studies, 8(1), 117-138.

Abor, A. \& Quartey, P. (2010). SME development in Ghana and South Africa. International Research Journal of finance and Economics, 39, 218-228.

Akhavan, P. \& Jafari, M. (2008). Towards learning in SMEs: an empirical study in Iran. Development and Learning in Organizations, 22(1), 17-20.

Akhtar, S., Arif, A., Rubi, E. \& Naveed, S. (2011). Impact of organizational learning on organizational performance: Study of higher education institutes. International Journal of Academic Research, 3(5), 327-331.

Altbach, P. G., Reisberg, L. \& Rumbley, L. E. (2009). Trends in global higher education: Tracking an academic revolution. Report prepared for the UNESCO 2009 World Conference on Higher Education. UNESCO Publishing. Paris. Available at http://unesdoc.unesco.org/images/0018/001831/183168e.pdf. Accessed on 22 July 2016.

Austin, M. S. \& Harkins, D. A. (2008). Assessing change: can organizational learning "work" for schools. The Learning Organization, 15(2), 105-125.

Ayse, S. H. (2010). Organizational learning as a situated routine-based activity in international settings. Journal of World Business, 45(1), 41-48.

Bakar, H. A., Mamatm, L., Ramlee, N. A. Z., Sama, M. F. \& Karim, Z. H. A. (2016). Effect of Entrepreneurial Orientation, Learning Orientation, Strategic Improvisation on SME Performance. International Journal of Management and Applied Science, 2(12), 57-62.

Baker, W. E. \& Sinkula, J. M. (2007). Does market orientation facilitate balanced innovation programs? An organizational learning perspective. Journal of Product Innovation Management, 24(4), 316-334.

Barney, J. B. (1991). Firm resources and sustained competitive advantage. Journal of Management, 17(1), 99120.

Beneke, J., Beneke, J., Blampied, S., Blampied, S., Dewar, N., Dewar, N., Soriano, L. \& Soriano, L. (2016). The impact of market orientation and learning orientation on organizational performance: A study of small to medium-sized enterprises in Cape Town, South Africa. Journal of Research in Marketing and Entrepreneurship, 18(1), 90-108.

Bierly, P. E. \& Daly, P. S. (2007). Alternative knowledge, competitive environment, and organisational performance in small manufacturing firms. Entrepreneurship Theory and Practice, 31(4), 493-516.

Chang, S. C. \& Lee, M. S. (2007). A study on relationship among leadership, organizational culture, the operation of learning organization and employee's job satisfaction. The Learning Organization, 14(2), 155-185.

Cooper, D. R. \& Schindler P. S. (2008). Marketing Research. International Edition 10thed. New York: McGrawHill/ Irwin.

Department of Trade and Industry (DTI). (2012). White paper on national strategy for the development and promotion of small business in South Africa. Pretoria: Government Publications.

Dill, D. \& Van Vught, F. (2010). National innovation and the academic research enterprise: Public policy in global perspective. (eds). Baltimore: The John Hopkins University Press.

Dubihlela, J. (2013). Determinants of market orientation adoption among small and medium enterprises (SMES) in South Africa. Mediterranean Journal of Social Sciences, 4(6), 55-65.

Eris, E. D., Ozmen, T. \& Neczan, 0. (2012). The effect of marketing orientation, learning orientation and innovativeness on firm performance: A research from Turkish logistics sector. International Journal of Economic Science and Applied Research, 5(1), 77-108.

Espedal, B. (2008). In the pursuit of understanding how to balance lower and higher order learning in organizations. Journal of Applied Behavioural Science, 44, 365-390.

Fatoki, O. \& Garwe, D. (2010). Obstacles to the growth of new SMEs in South Africa: A principal component analysis approach. African Journal of Business Management, 4(5), 729-738.

Gnyawall, D. R., Singal, M. \& Mu, S. C. (2009). Knowledge ties among subsidiaries in Mncs: A multi-level conceptual model. Journal of International Management, 15, 387-400.

Hair, J. F., Anderson, R. E., Tatham, R. L. \& Black, W. C. (2006). Multivariate data analysis with readings. Englewood Cliffs: NJ, Prentice Hall. 
Haryanto, A. T., Haryono, T. \& Sawitri, H. S. R. (2017). Market Orientation, Learning Orientation and SMES Performance: The Mediating Role of Innovation. International Review of Management and Marketing, $7(1), 484-491$.

Herrington, M. \& Kew, J. (2013). The Global Entrepreneurship Monitor (GEM): South African report. UCT Development Unit of New Enterprise, Cape Town, 1-48.

Huang, S. K. \& Wang, Y. L. (2011). Entrepreneurial orientation, learning orientation and innovation in small and medium enterprises, in Proceedings of 7 th International Strategic Management Conference. Procardia Social and Behavioural Science, 24, 563-570.

Hult, G. T. M., Ketchen, D. J. \& Slater, S. F. (2007). Strategic supply chain management: improving performance through a culture of competitiveness and knowledge development. Strategic Management Journal, 28, 1035-1052.

Hussein, N., Mohamad, A., Noordin, F. \& Ishak, N. A. (2014). Learning orientation and its effects on organisational performance and organizational innovativeness a proposed framework for Malaysia public institution of higher education. Procedia-Social and Behavioural Science, 130, 299-304.

Idar, R. \& Mahmood, R. (2011). Entrepreneurial and marketing orientation relationship to performance: the SME perspective. Interdisciplinary Review of Economics and Management, 1(2), 1-8.

Jyathibabu, C., Faroog, A. \& Pradhan, B. B. (2010). An integrated scale for measuring an organisational learning system. Learning Organisation, 17(4), 303-327.

Kafouros, M. I., Buckley, P. J. \& Clegg, J. (2012). The effect of global knowledge reservoirs on the productivity of multinational enterprises; the role of international depth and breadth. Research Policy, 41, 848861.

Konidari, V. \& Yvan, A. (2006). From TQM to learning organization: Another way for quality management in educational institutions. International Journal of Quality, Reliability Management, 23(1), 8-26.

Kotabe, M., Dunlap-Hinkler, D., Parente, R. \& Mishra, H. A. (2007). Determinants of cross-national knowledge transfer and its effect on firm innovation. Journal of International Business Studies, 38, 259-282.

Kreiser, P. M. (2011). Entrepreneurial orientation and organizational learning: The impact of network range and network closure. Entrepreneurship Theory and Practice, 35(5), 1042-2587.

Lages, L. F., Silva, G., Styles, C. \& Pereira, Z. L. (2009). The NEP scale: A measure of network export performance. International Business Review, 18, 344-356.

Lai, C. S., Pai, D. C., Yang, C. F. \& Lin, H. J. (2009). The effects of market orientation on relationship in industrial marketing: The dyadic perspectives. Industrial Marketing Management, 38(2), 166-172.

Liu, C. L. E. (2012). An investigation of relationship learning in cross-border buyer-supplier relationships: The role of trust. International Business Review, 21, 311-327.

Lu, Y., Zhou, L., Bruton, G. \& Li, W. (2010). Capabilities as a mediator linking resources and the international performance of entrepreneurial firms in an emerging economy. Journal of International Business Studies, 41, 419-436.

Machirori, T. \& Fatoki, O. (2013). The Impact of Firm and Entrepreneur's Characteristics on Networking by SMEs in South Africa. Journal of Economics, 4(2), 113-120.

Mahmood, R. \& Hanafi, N. (2013). Learning orientation and business performance of women-owned SMES in Malaysia: the mediating effect of competitive advantage. British Journal of Arts and Social Sciences, 11(II), 2046-9578.

Masocha, R. \& Dzomonda, O. (2016). The mediating role of effective working capital management on the growth prospects of Small and Medium Enterprises in Polokwane Municipality. 5th Annual SAAPAM conference. Limpopo Chapter.

Nasution, H. N. \& Mavondo, F. T. (2008). Organisational capabilities: Antecedents and implications for customer value. European Journal of Marketing, 42(3/4), 477-501.

Nasution, H. N., Mavondo, F. T., Matanda, M. J. \& Ndubisi, N. O. (2011). Entrepreneurship: Its relationship with market orientation and learning orientation and as antecedents to innovation and customer value. Industrial Marketing Management, 40, 336-345.

Nybakk, E. (2012). Learning orientation, innovativeness and financial performance in traditional manufacturing firms: a higher-order structural equation model. International Journal of Innovation Management, 16(5), 24- 28.

Rebelo, T. M. \& Gomes, A. D. (2011). Conditioning factors of an organizational learning culture. Journal of Workplace Learning, 23(3), 173-194. 
Rhee, J., Park, T. \& Lee, D. H. (2010). Drivers of innovativeness and performance for innovative SMEs in South Korea: Mediation of learning orientation. Technovation, 30, 65-75.

Salavou, H. (2005). Do customers and technology orientations influence product innovativeness in SMEs? Some new evidence from Greece. Journal of Marketing Management, 21(3/4), 307-338.

Saru, E. (2007). Organizational Learning and HRS: how appropriate are they for small firms. Journal of European Industrial Training, 31(1), 36-51.

Shih, K. H., Chang, C. J. \& Lin, B. (2010). Assessing knowledge creation and intellectual capital in banking industry. Journal of Intellectual Capital, 11(1), 74-89.

Small Enterprise Development Agency Report. (2012). Analysis of the needs, state and performance of small and medium businesses in the agriculture, manufacturing, ICT and tourism sector in South Africa. Available at http://www.seda.org.za/publication/publication/analysis. Accessed 28/ July/ 2016

Statistics South Africa. (2016). Quarterly labour force survey. Accessed 12 September 2014 Available at http:/www.statssa.gov.za publication/P02111stQuater2016.pdf. Accessed on 28 July 2016.

Suliyanto, S. \& Rahab, R. (2012). The role of market orientation and learning orientation in improving innovativeness and performance of small and medium enterprises. Asian Social Sciences, 8(1), 134145.

Tsele, L. (2015). Female entrepreneurship: Is South Africa winning the gender inequality struggle? Available:http://www.smesouthafrica.co.za/15922/Female-entrepreneurship-Is-South-Africawinning-the-gender-inequality-struggle/. Accessed on 29 May 2017.

Van Scheers, L. (2012). Marketing related challenges of small and medium enterprises (SMEs) in developing African countries: the South African challenge. African Journal of Business Management, 5(13), 50485056.

Willesse, J. (2010). The forum SA SME fairer statistics. Available at http//www.theforumsa.co.za/forum/showthread.php?t=7808. Accessed on 19 September 2014.

World Bank. (2015). The Big Business of Small Enterprises: Evaluation of the World Bank Group Experience with Targeted Support to Small and Medium-Size Enterprises. Available at https://books.google.co.za/books?isbn=146480377. Accessed On 15 July 2015. 